Елена Анатольевна Хорошавина

https://orcid.org/0000-0001-9792-0134

кандидат искусствоведения, и.о. доцента

кафедры народных инструментов

ОНМА имени А. В. Неждановой

elkhguitar@ukr.net

\title{
ПУТИ ФОРМИРОВАНИЯ ИСПОЛНИТЕЛЬСКОЙ СЕРБСКОЙ ГИТАРНОЙ ТРАДИЦИИ: ОТ НАЦИОНАЛЬНО- КУЛЬТУРНЫХ УСТАНОВОК К УНИКАЛЬНЫМ СТИЛИСТИЧЕСКИМ ПРИЕМАМ
}

\begin{abstract}
Целью статьи является стремление рассмотреть исполнительскую сербскую традицию в единстве ее национально-культурных установок и уникальных стилистических приемов. Методология предполагает единство таких методических подходов, как историографический, историко-культурологический, жканрово-стилевой, интерпретативно-текстологический, семиологический и герменевтический. Научная новизна определяется, с одной стороны, выявлением новых путей изучения сербской национальной культуры, с другой - углубленным изучением уникальных стилистических приемов в сербском гитарном исполнительстве. Выводы. Исполнительская сербская гитарная традиция представляет собой подвижную и динамично развиваюшуюся систему, продуцируюшую новые творческие идеи и способы их реализации. Исполнительская сербская гитарная традиция одновременно выражает и общие коллективные установки, и уникальные индивидуальные черты, основываясь при этом на исторических и культурных национальных установках. Творчество выдающейся творческой индивидуальности, композитора и исполнителя Уроша Дойчиновича является узловым моментом истории сербского гитарного искусства ХХ - начала ХХІ в., поскольку представляет, с одной стороны, народную музыкальную культуру, которая имеет национальное самосознание и коллективные мировоззренческие установки. С другой стороны, оно воплощает профессиональные композиторские принципы, связанные с академическими традициями гитарного искусства и с формами и принципами существования музыкально-исполнительской деятельности.
\end{abstract}

Ключевые слова: гитарное исполнительство, исполнительская сербская гитарная традиция, национальные культурные установки, исполнительский стиль, стилистические приемы. 
Khoroshavina Elena Anatolievna, Ph.D. in History of Arts, Associate Professor of Department of Folk Instruments of Odessa National A. V. Nezhdanova Academy of Music

Ways of forming the Serbian performing guitar tradition: from national cultural settings to unique stylistic techniques

The purpose of this article is the desire to consider the performing Serbian tradition in the unity of its national-cultural settings and unique stylistic techniques. The methodology assumes the unity of such methodological approaches as historiographic, historical and cultural, genre-style, interpretive-textual, semiological and hermeneutic. Scientific novelty is determined on the one hand by the identification of new ways of studying the Serbian national culture, on the other - an in-depth study of unique stylistic techniques in the Serbian guitar performance. Findings. The Serbian performing guitar tradition is a fluid and dynamically developing system, producing new creative ideas and ways to implement them. The performing Serbian guitar tradition simultaneously expresses both common collective settings and unique individual traits, based on historical and cultural national settings. The work of the outstanding creative individuality, the composer and performer Uros Dojchinovic is a focal point of the history of Serbian guitar art of the XX - early XXI century, as it represents, on the one hand, folk musical culture, which has a national identity and a collective worldview. On the other hand, it embodies the professional composer principles associated with the academic traditions of guitar art and with the forms and principles of the existence of musical and performing activities.

Keywords: guitar performance, performing Serbian guitar tradition, national cultural setting, performing style, stylistic techniques.

Хорошавіна Олена Анатоліївна, кандидат мистецтвознавства, в.о. доцента кафедри народних інструментів

ШАяхи формування виконавської сербської гітарної традиції: від національно-культурних настанов до унікальних стилістичних прийомів

Метою статті є прагнення розглянути виконавську сербську традицію в єдності ї̈ національно-культурних настанов та унікальних стилістичних прийомів. Методологія передбачає єдність таких методичних підходів, як історіографічний, історико-культурологічний, жканровостильовий, інтерпретативно-текстологічний, семіологічний та герменевтичний. Наукова новизна визначається, з одного боку, виявленням нових шляхів вивчення сербської національної культури, з іншого - поглибленим вивченням унікальних стилістичних прийомів в сербському гітарному виконавстві. Висновки. Виконавська сербська гітарна традиція $\epsilon$ рухливою системою, що динамічно розвивається, яка продукує нові творчі ідеї та способи їх реалізації. Виконавська сербська гітарна традиція одночасно висловлюе і загальні колективні настанови, й унікальні індивідуальні риси, спираючись при цьому на історичні і культурні національні установки. Творчість видатної творчої індивідуальності, композитора 
і виконавия Уроша Дойчіновіча є вузловим моментом історії сербського гітарного мистецтва $X X-$ початку XXI ст., оскільки представляє, з одного боку, народну музичну культуру, яка має національну самосвідомість і колективні світоглядні установки. 3 іншого боку, вона втілюе професійні композиторські принципи, пов'язані з академічними традиціями гітарного мистецтва $i$ з формами і принципами існування музично-виконавської діяльності.

Ключові слова: гітарне виконавство, виконавська сербська гітарна традиція, національні культурні установки, виконавський стиль, стилістичні прийоми.

Актуальность данной статьи объясняется тем, что сербская музыкальная культура представляет уникальный образец формирования и сохранения национальной идеи, несмотря на все сложности, которые возникали в процессе ее исторического пути. Феномен гитарного искусства занимает в ней очень заметное место, однако с музыковедческих позиций это явление изучено недостаточно. Национальное становится тем катализатором, благодаря которому осуществляются кардинальные изменения в искусстве и поиск новых форм выражения культурной, в том числе исполнительской традиции, сопровождается существенным реформированием музыкального языка, находит свое выражение в формировании сербской исполнительской гитарной традиции.

Целью статьи является стремление рассмотреть исполнительскую сербскую традицию в единстве ее национально-культурных установок и уникальных стилистических приемов. Методология предполагает единство таких методических подходов, как историографический, историко-культурологический, жанрово-стилевой, интерпретативно-текстологический, семиологический и герменевтический. Научная новизна определяется, с одной стороны, выявлением новых путей изучения сербской национальной культуры, с другой - углубленным изучением уникальных стилистических приемов в сербском гитарном исполнительстве.

Изложение основного материала. Проблема изучения генезиса гитарного искусства на Балканах в целом и в Сербии в частности оставалась практически открытой до недавнего времени. Благодаря исследовательским работам У. Дойчиновича, основанным на археографических материалах, стало возможным прослеживание динамики развития и выстраивание общей линии генезиса гитарного искусства региона в европейском культурном контексте. Наряду с этим 
чрезвычайно важным вопросом при рассмотрении формирования сербской исполнительской гитарной традиции оказывается проблема национальной идентичности.

Св. Николай (Велимирович) подчеркивает, что одним из опорных моментов является народная нераздельная целостность, как физическая, так духовная и нравственная, в связи с чем «все грани народной жизни и установок нераздельны, соединены не механически одна с другой, но срослись так, что соки одной питают другую» $[4,574]$. Автор указывает, что в этом органичном и священном понимании нации коренится уникальная трактовки национальной культуры - «Евангельский и органичный национализм». Евангельским он именует национализм за то, что «он защищает личность человека и способствует ее развитию до совершенства», органическим он его называет за то, что «он защищает индивидуальность самого народа как цельности, чтобы не соблазниться империализмом или не рассеяться в интернационализме» [4, 574-575].

Полная драматических событий судьба сербского народа, на земли которого на протяжении многих веков претендовали в разное время Турция, некоторые европейские страны, Болгарское царство, возможно, стала причиной формирования уникальных особенностей сербского национального характера. Автор исследования о сербской нации и стране М. Э. Дурхам писала еще в начале XX века о том, что изучая историю Сербии, можно сделать вывод, что «это одна постоянная боль», так как различные потрясения и гонения христианских народов на Балканах, начавшиеся с приходом турок, будут продолжаться до тех пор, пока турки не оставят эти земли [5]. Известно, что в 1690 г. из Старой Сербии в Венгрию вынуждены были переселиться почти 37 тысяч задруг (семейные группы от 50 до 80 человек, которые включают и братьев с их семьями). Не удивительно, что национальная идея в Сербии выражена столь ярко, однако не только осознание своей причастности к сербской нации особо примечательно, внимание привлекает и абсолютная готовность к личной жертве.

Подтверждением этого выступают размышления Д. Майерса о Я-концепции в социуме, где в качестве особо показательного примера он называет «такие определения, как «серб», «тамил», «курд» и «эстонец», - внутригрупповые идентификации, ради которых люди готовы на смерть» [3]. Собственно, воинствующее охранение своей национальной идентичности связано у сербов не просто с «памятью предков», но именно с защитой своих православных устоев. Их «на- 
ционализм» - это скорее «здравое и веками выстраданное ощущение национальной самодостаточности, гордость за свою историю и деяния своих предков, а также горечь за многовековой геноцид сербов» [6].

Как указывает в своем исследовании А. Кулиш, сербская национальная идентичность опирается на события XII-XIV веков (сербское государство Неманичей - Сербская деспотовина) и Первое сербское восстание 1804-1813 гг., которое возглавил Карагеоргий, затем в 1815 году второе восстание под руководством Милоша Обреновича и создание Сербского княжества. Трактуемую в своем понимании духовность - национальный тип духовности, характеризуется особым комплексом аксиологических и нравственно-эстетических ориентиров и эмоциональных предпочтений следует отнести к числу базовых характеристик сербской культуры. Вся история сербского народа, находящегося в процессе постоянного сохранения и охранения своего жизненного и культурного пространства, неразрывно связана с православием. Именно православное вероучение явилось той мифопоэтической, культурной, религиозной, мировоззренческой базой, которая и определила национальный характер сербского народа [2].

В сербской музыкальной культуре ярко проявлялись несколько тенденций, а именно мощное воздействие византийской музыкальной традиции, народной сербской музыкальной культуры и влияние музыкальной культуры восточных стран. О тесной связи между сербской и византийской музыкальной традициями писали многие исследователи, приводя в качестве доказательств отсутствие и в одной и в другой музыкальной традиции наличия скачков на большие интервалы (кварта, квинта и т. д.), стремительных гаммообразных и арпеджированных пассажей [8].

С другой стороны, выдающихся византинист и историк Эгон Велес указывал, что, говоря о византийской музыкальной культуре, нельзя не учитывать тот факт, что империя объединяла огромные территории, включающие в себя множество различных музыкальнокультурных проявлений, характерных для стран Малой Азии, Сирии, Месопотамии и Египта и их влияние нельзя исключать. Вероятность диалога культур усиливалась и в связи с особенностью географического местоположения Сербии.

Динамичное развитие исполнительской сербской гитарной традиции как профессиональной формы музицирования и активный рост сербской исполнительской гитарной школы приходится на 
первую половину XX столетия. Следует особо отметить, что главным образом подобное бурное развитие сербского академического гитарного исполнительства основывается на деятельности ряда ярких творческих личностей, внесших неоценимый вклад в развитие этого вида искусства. В первую очередь следует обратиться к творческой деятельности известного сербского композитора и гитариста Йована Йовичича (Jovan Jovičić), который проявил себя не только как исполнитель, композитор, педагог, но еще и как исследователь. Им был опубликован ряд научных работ касательно акустических возможностей гитары.

В конце 1950-х - начале 1960-х годов на протяжении четырех лет он учился у Андреса Сеговии в Музыкальной академии Киджана в Сиене (Италия). Впоследствии великий учитель говорил о Йоване Йовичиче: «Я с большим удовольствием констатирую, что югославский гитарист Йован Йовичич за время обучения в академии Киджана в моем классе добился огромных успехов в овладении инструментом как в художественном, так и в техническом отношениях. Его ждет блестящая карьера исполнителя и педагога» [1]. Спустя много лет Андрес Сеговия подтвердил собственную характеристику и назвал Йована Йовичича одним из наиболее талантливых своих учеников, «большим мастером гитары», чье мастерство заслуживает восхищения.

Активную концертную деятельность Й. Йовичич начал в 1948 году, одно из его выступлений состоялось в прямом эфире на радио Дубровника и Белграда, что стало первым случаем концертной трансляции, в которой звучала сольная гитара. В репертуаре его концертных выступлений звучала самая различная музыка - от произведений композиторов Ренессанса, эпохи барокко, вплоть до самых современных на тот момент гитарных произведений. При этом большом разнообразии исполнительского репертуара значительное место он отводил произведениям, относящимся к национальной музыкальной традиции, основанным на народных темах. Более пятидесяти лет активной и плодотворной творческой деятельности стали значительным вкладом в популяризацию в Югославии классической гитары как сольного инструмента. Автором было опубликовано значительное количество научных работ, освещающих вопросы гитарного исполнительства, в том числе «Гитарный метод» в пяти томах, которых получил наивысшую оценку у ведущих гитаристов мира - Андреса Сеговии и Алирио Диаса. 
Среди современных сербских гитаристов совершенно особое место занимает Урош Дойчинович (Uros Dojcinovic), блестящий гитарист-исполнитель, композитор, музыковед, педагог, издатель и значительный общественный деятель. Урош (Зоран) Дойчинович родился 15 мая 1959 года в г. Белграде, Республика Сербия (бывшая Югославия). В своем интервью, которое У. Дойчинович дал автору данной работы, он подчеркивал важность для формирования его творческой индивидуальности начального образования.

Он начал обучаться игре на гитаре в детском возрасте, приблизительно с семи лет, и первым его учителем был не педагог-гитарист в академическом учебном заведении, а наставник по гитаре, человек, который исполнял популярную и народную музыку - Бранко Перешич. Примечательна была его исполнительская манера, так как наряду со звукоизвлечением пальцами он зачастую играл медиатором. Дальнейшее образование У. Дойчинович продолжил в классе Нади Кондич, которая по базовому образованию была скрипачкой и теоретиком в начальной и средней музыкальная школе «Йосипа Славенски» Белград (Сербия) [7].

Н. Кондич возглавляла первый класс гитары в белградской музыкальной школе и стала основательницей мощной традиции гитарного исполнительства. В ее классе обучались многие выдающиеся исполнители-гитаристы, внесшие значительный вклад в развитие национального искусства игры на гитаре, в том числе и Душан Богданович. После завершения общего среднего и музыкального образования У. Дойчинович поступил на филологический факультет Белградского университета для изучения словесности и литературы.

Подчеркнем, что по окончании специализированной музыкальной школы и средней школы У. Дойчинович стал первым в Белграде выпускником, который закончил основную и среднюю музыкальную школы по гитаре и мог поступать в музыкальную академию. На тот момент в Югославии была единственная музыкальная академия в г. Загребе, где в 70-х годах XX столетия был открыт класс гитары. Первым преподавателем У. Дойчиновича в академии стал композитор Станко Прек [7].

Он был первым профессором по классу гитары, который обучал югославских музыкантов, в том числе и переквалифицирующихся преподавателей. Первое поколение музыкантов (не гитаристов), к которому относилась и Надя Кондич, приезжали к Станко Преку из всей Югославии и проходили у него курс переквалификации. Это был короткий курс, рассчитанный на два года, с периодичностью за- 
нятий 1-2 дня в месяц, и за два года обучающиеся получали азы и осваивали основы исполнительских и технических приемов, а затем становились первыми преподавателями по классу гитары в музыкальных школах Югославии.

Поэтому именно Урош Дойчинович стал одним из первых гитаристов, который не только получил высшее образование, но и продолжил свое дальнейшее обучение в аспирантуре Белградского университета по специальности музыковедение. Результатом обучения стало написание двух диссертационных исследований («Класична гитара у Југоисточној Европи до 1941 године»; «Српска гитаристичка литература 1941-2000»), которые объединяли в себе его научный интерес к музыкальному искусству, филологии и истории. Помимо этой работы У. Дойчиновичем написано достаточно большое количество исследовательских работ, многие из которых открывают совершенно неизученные страницы гитарного искусства («Following the Guitar Trails in Yugoslavia», «Gitara na Balkanu», «The Guitar Triumph», «Secret of the Guitar», «Tragom gitare u Makedoniji» и мн. др.) Иными словами, музыковедческая специализация определила еще один важный аспект деятельности У. Дойчиновича - научный, он написал значительное количество научных и исследовательских работ, затрагивающих вопросы гитарного искусства, подготовил большое количество лекций и мастер-классов [7].

Важной стороной творческой индивидуальности Уроша Дойчиновича, определившей во многом пути его развития, становится исполнительская деятельность. В творческом «багаже» У. Дойчиновича чрезвычайно активная концертная деятельность - им дано более 3000 концертов по всему миру (сольных, с различными составами, в синкретических музыкальных программах и т. д.); большое количество записей на радио и телевидении; значительное количество фондовых записей - более 60 записей на разных носителях, изданных разными компаниями. Совершенно отдельного внимания заслуживает его композиторское творчество, которое насчитывает более 600 произведений, написанных в разных жанрах и для различных составов. Здесь мы встречаем и оригинальные произведения для гитары соло, камерные произведения, транскрипции, аранжировки и переложения.

Он является одним из основателей и художественным руководителем Первого югославского фестиваля гитары (Заечар, 86), а затем Международной гитарной серии GITAFES (Смедерево), Междуна- 
родного фестиваля гитары SORABIJA (Niљ), Международного фестиваля камерной музыки OLD-GOLD (Ниш), Международного фестиваля классической музыки VRNJCI (Vrnjačka Banja), Savicium Classic Fest (Љabac) и т. д. Он также является основателем и президентом Югославской гитарной Ассоциации.

У. Дойчинович выступает как постоянный член Ассоциации музыкальных деятелей Сербии, Ассоциации композиторов Черногории и Матицы сербской в Нови-Сад (Montenegro and Matica srpska in Novi $\mathrm{Sad}$ ), а также членом Гитарного Фонда Америки (Guitar Foundation of America), Британского реестра гитарных учителей РГТ (The British Registry of Guitar Tutors RGT) и т. д. Урош Дойчинович ведет постоянную преподавательскую деятельность с 1978 года. Он работал в нескольких музыкальных школах в Загребе (Хорватия) и Белграде (Сербия), а с 1989 года был приглашенным лектором и профессором в большом количестве иностранных образовательных музыкальных учреждений (музыкальные консерватории, академии, университеты и т. д.) [7].

Урош Дойчинович является частым участником или главой жюри национальных и международных конкурсов для инструменталистов и композиторов, приглашается в качестве эксперта, как музыкальный лектор и преподаватель на мастер-классы и семинары в своей стране и за рубежом. За многолетнюю артистическую деятельность Дойчинович был награжден более чем 50 различными медалями, грамотами, дипломами и другими наградами в стране и за рубежом. Выступая в качестве культурного «Посла со своим инструментом» («Нация - Малайзия, 1992 год») «Ambassador with his instrument «(The Nation - Malaysia, 1992), Урош Дойчинович стал американским почетным гражданином (Техас, 1992 год).

Урош Дойчинович также является создателем новой учебной программы обучения на классической гитаре в Республике Сербия (1987/1993) и автором специальной сербской методической и учебной литературы для гитаристов. И наконец, У. Дойчинович является автором первой написанной и опубликованной истории классической гитары в бывшей Югославии, охватывая в своем исследовании историю гитарного исполнительства не только Сербии, но и Черногории, Македонии и других балканских стран. Эти исследовательские работы имеют чрезвычайное значение, так как во многом объясняют те процессы, которые происходят в современном сербском гитарном исполнительстве. 
Выводы. Исполнительская сербская гитарная традиция представляет собой подвижную и динамично развивающуюся систему, продуцирующую новые творческие идеи и способы их реализации. Она одновременно выражает и общие коллективные установки, и уникальные индивидуальные черты, основываясь при этом на исторических и культурных национальных установках. Творчество выдающейся творческой индивидуальности, композитора и исполнителя Уроша Дойчиновича является узловым моментом истории сербского гитарного искусства XX - начала XXI в., поскольку представляет, с одной стороны, народную музыкальную культуру, которая имеет национальное самосознание и коллективные мировоззренческие установки; с другой - воплощает профессиональные композиторские принципы, связанные с академическими традициями гитарного искусства и с формами и принципами существования музыкально-исполнительской деятельности.

\section{СПИСОК ЛИТЕРАТУРЫ}

1. Йован Йовичич [Электронный ресурс]. Гитаристы и композиторы. URL: http://guitarmag.net/wiki/index.php

2. Кулиш А. Актуальные исполнительские формы сербского баянно-аккордеонного искусства: дис. ... канд. искусствоведения: [спец.] 17.00.03 - музыкальное искусство. Одесса, 2013. 192 с.

3. Майерс Д. Социальная психология / пер. с англ. В. Гаврилова, С. Шпака, С. Меленевской, Д. Викторовой. СПб.: Питер КОМ, 1998. 688 с.

4. Святитель Николай Сербский (Велимирович). Национализм святого Саввы. Святитель Николай Сербский. Собрание сочинений. Линц: Изд-во Православной церковной общины. 2001. Кн. 2. С. 572-578.

5. Терзич С. Судьба Югославии и роль России [Электронный ресурс]. Российские и югославские эксперты о ситуации на Балканах. URL: bulsectionid=247

6. Традиция [Электронный ресурс]. Календарь Сербской Православной церкви. URL: http://www.crkvenikalendar.com/tradition_ru.php

7. Хорошавина Е. Творческая личность Уроша Дойчиновича в контексте современного гитарного искусства: дис. ... канд. искусствоведения: [спец.] 17.00.03 - музыкальное искусство. Одесса, 2017. 165 с.

8. Petrovic R. Srpska narodna muzika. Beograd: Naucna knjiga, 1982. 158 s.

\section{REFERENCES}

1. Jovan, Jovicic // Guitarists and composers: electronic resource. URL: http:// guitarmag.net/wiki/index.php [in Russian]

2. Kulish, A. (2013). Actual performing forms of Serbian accordion-accordion art: Diss. for competition uch. degree of candidate art history: [spec.] 17.00.03 Musical art. Odessa. [in Russian] 
3. Myers, D. (1998). Social psychology. SPb. : Peter Kom. [in Russian]

4. St. Nicholas the Serbian, (Velimirovich). (. 2001). The nationalism of St. Sava // St. Nicholas the Serbian. Collected Works. Publisher of the Orthodox Church Community Linz. Vol. 2. [in Russian]

5. Terzic, S. The fate of Yugoslavia and the role of Russia. Russian and Yugoslav experts on the situation in the Balkans: an electronic resource. URL: bulsectionid $=247$. [in Russian]

6. Tradition // Calendar of the Serbian Orthodox Church: an electronic resource. URL: http://www.crkvenikalendar.com/tradition_ru.php. [in Russian]

7. Khoroshavina, E. (2017). Creative personality of Uros Doychinovich in the context of contemporary guitar art: diss. for competition uch. degree of candidate art history: [spec.] 17.00.03 Musical art. Odessa. [in Russian]

8. Petrovic, R. (1982) Srpska narodna muzika. Beograd: Naucna knjiga. [in Serbian]

Стаття надійшла до редакції 20.09.2017

УДК 78.03+78.071.2/78.071.4

Тетяна Олександрівна Федиун

https://orcid.org/0000-0002-7082-8618

кандидат мистецтвознавства, в.о. доцента кафедри концертмейстерства

Одеської національної музичної

академії імені А. В. Нежданової

tati.fedch@gmail.com

\title{
ІСТОРИЧНІ УМОВИ КОНЦЕРТУВАННЯ \\ ЗАХІДНОУКРАЇНСЬКИХ ПІАНІСТІВ ЗА МЕЖАМИ РЕГІОНУ I HA ТЕРЕНАХ ЗАРУБІЖЖЯ У XIX-XX ст.
}

\begin{abstract}
Метою статті $\epsilon$ вияв історичних умов концертування західноукраїнських піаністів як прояв полікультурних складових у піаністичних традиціях регіону. Наукову новизну роботи визначають пріоритети аналізу впливу індивідуальних здобутків видатних представників європейського мистецтва на формування національної традиції у галузі фортепіанного виконавства й педагогіки та оцінки внеску західноукраїнських піаністів у мистецьке життя та фортепіанну педагогіку української діаспори. Методологія базується на міждисииплінарному підході, що дозволяє розглядати предмет дослідження в історичному, соціокультурному та музикознавчому аспектах. В роботі застосовано ряд методів, серед яких провідними є: теоретичний, історичний, аналітичний, ретроспективний, структурно-системний та компаративістський. Висновки. Уміж-
\end{abstract}

